\title{
Effects of extraction conditions on the redox properties of soil organic matter (SOM) and its ability to stimulate microbial iron(III) mineral reduction by electron shuttling
}

\author{
Yuge Bai ${ }^{1}$, Edisson Subdiaga ${ }^{2}$, Stefan B. Haderlein ${ }^{2}$, Heike Knicker $^{3}$, Andreas Kappler ${ }^{1}$ \\ ${ }^{1}$ Geomicrobiology, Center of Applied Geosciences, University of Tuebingen, Tuebingen, 72074, Germany \\ ${ }^{2}$ Environmental Mineralogy and Chemistry, Center of Applied Geosciences, University of Tuebingen, \\ Tuebingen, 72074, Germany \\ ${ }^{3}$ Instituto de Recursos Naturales y Agrobiología de Sevilla, Consejo Superior de Investigaciones Científicas \\ (IRNAS-CSIC), Seville, 41012. Spain \\ Correspondence to: Andreas Kappler (andreas.kappler@uni-tuebingen.de)
}

SUPPORTING INFORMATION

Number of tables in supporting information: 5

Number of figures in supporting information: 4

Total number of pages of supporting information: 10 (including cover page) 
Table S1. Two-way ANOVA statistical analysis of the measured specific UV absorbance values at $254 \mathrm{~nm}\left(\mathrm{SUVA}_{254}\right)$ for all NOM extracts. The two-way ANOVA analysis was conducted using the SPSS software to test whether the oxic extraction conditions, the extraction method, or both of them have significant impact on the $\mathrm{SUVA}_{254}$ values of the extracts. $\mathrm{P}<0.05$ indicates the rejection of the null hypotheses, meaning that the corresponding condition has significant influence on the $\mathrm{SUVA}_{254}$.

${ }^{\mathrm{a} D e p e n d e n t ~ V a r i a b l e: ~} \mathrm{SUVA}_{254}$

\begin{tabular}{lccccc}
\hline Conditions & $\begin{array}{c}\text { Sum of } \\
\text { Squares }\end{array}$ & $\begin{array}{c}{ }^{\mathrm{b}} \text { Degrees of } \\
\text { freedom }\end{array}$ & ${ }^{\mathrm{c}}$ Mean Square & ${ }^{\mathrm{d}} \mathrm{F}$ & $\mathrm{P}$ \\
\hline $\begin{array}{l}\text { Oxic extraction conditions (oxic } v s . \\
\text { anoxic) }\end{array}$ & 0.002 & 1 & 0.002 & $\mathrm{~F}(1.20)=4.35<0.05$ \\
& & & & 11.181 & 166.808 \\
$\begin{array}{l}\text { Extraction method (water } v s . \\
\text { chemical) }\end{array}$ & 0.125 & 4 & 0.031 & $\mathrm{~F}(4.20)=2.87<0.05$ \\
$\begin{array}{l}\text { Oxic extraction conditions and } \\
\text { extraction method }\end{array}$ & 0.077 & 4 & 0.019 & $\mathrm{~F}(4.20)=2.87$ & $<0.05$ \\
\begin{tabular}{l} 
Error (within group variances) \\
\hline
\end{tabular} & 0.004 & 20 & $\begin{array}{c}0.000 \\
(0.00018)\end{array}$ & & \\
\hline
\end{tabular}

${ }^{\mathrm{a}}$ Three null hypotheses of the two-way ANOVA analysis:

Hypothesis $_{\mathrm{n} 1}$ : the oxic conditions do not have significant impact on the measured SUVA 254 values of the extracts Hypothesis $_{\mathrm{n} 2}$ : the extraction method does not have significant impact on the measured $\mathrm{SUVA}_{254}$ values of the extracts Hypothesis $_{\mathrm{n} 3}$ : the oxic conditions and the extraction method together do not have any significant impact on the measured $\mathrm{SUVA}_{254}$ values of the extracts

${ }^{b}$ Degree of Freedom was calculated based on the number of variables under each condition. For example, under oxic extraction conditions, there are two variables, i.e., oxic conditions or anoxic conditions, so the degree of freedom is $2-1=1$. For the extraction method, there are five variables, i.e., water-extracted SOM, water-extracted FA, chemically-extracted FA, water-extracted HA, chemically extracted HA, therefore the degree of freedom is 5-1 $=4$. The degree of freedom of both conditions (the third row: oxic conditions and extraction method) was calculated by multiplying the degree of freedom of oxic extraction conditions and the degree of freedom of extraction method, therefore $1 \times 4=4$.

${ }^{\mathrm{c}}$ Mean Square $=$ Sum of Square/Degree of Freedom

${ }^{\mathrm{d}} \mathrm{F}$ ratio =variance of the group means (Mean Square)/mean of the within group variances (Mean Square Error). The calculated $\mathrm{F}$ ratio should be compared to the critical $\mathrm{F}$ ratio based on the degree of freedom (as shown in the brackets), and in all cases above, the $\mathrm{F}$ ratio was higher than the critical $\mathrm{F}$ ratio, indicating the null hypotheses should be rejected. 
Table S2. ${ }^{13} \mathrm{C}-\mathrm{NMR}$ analysis of SOM, FA and HA. All extracts were isolated from a forest soil (Schönbuch forest, Baden-Wuerttemberg, Germany) under oxic or anoxic conditions. ${ }^{13} \mathrm{C}$ NMR was conducted from freeze-dried extracts. The relative intensities of the signals were obtained by integration of the specific chemical shift ranges by an integration routine with MESTRE NOVA. Data for water-extracted FA cannot be presented due to the lack of an adequate amount of sample for analysis.

Percentage distribution of ${ }^{13} \mathrm{C}$ within indicated ppm regions $(\%)$

\begin{tabular}{|c|c|c|c|c|c|c|c|c|c|}
\hline $\begin{array}{l}\text { Sample/ppm } \\
\text { range }\end{array}$ & $0-45$ & $45-60$ & $60-90$ & $90-110$ & $110-140$ & $140-160$ & $160-185$ & $185-225$ & $\begin{array}{c}\text { Aromaticity }^{\mathrm{a}} \\
(\%)\end{array}$ \\
\hline & $\begin{array}{l}\text { Alkyl } \\
\text { C }\end{array}$ & $\begin{array}{c}N- \\
\text { Alkyl C }\end{array}$ & $\begin{array}{c}O- \\
\text { Alkyl C }\end{array}$ & $\begin{array}{c}O \text {-Alkyl \& } \\
C / H \text {-Aryl } \\
\mathrm{C} \\
\end{array}$ & $\begin{array}{c}C / H \text {-Aryl } \\
\text { C }\end{array}$ & $\begin{array}{c}\text { O-Aryl } \\
\text { C }\end{array}$ & Carbonyl C & $\begin{array}{c}\text { Aldehyde } \\
\& \\
\text { Ketone }\end{array}$ & \\
\hline $\begin{array}{l}\text { Water- } \\
\text { extracted } \\
\text { SOM, oxic }\end{array}$ & 20 & 10 & 30 & 10 & 12 & 6 & 7 & 4 & 20 \\
\hline $\begin{array}{l}\text { Water- } \\
\text { extracted } \\
\text { SOM, anoxic }\end{array}$ & 35 & 10 & 14 & 6 & 13 & 6 & 15 & 1 & 23 \\
\hline $\begin{array}{l}\text { Chem.- } \\
\text { extracted FA, } \\
\text { oxic }\end{array}$ & 21 & 9 & 32 & 9 & 9 & 4 & 11 & 3 & 15 \\
\hline $\begin{array}{l}\text { Chem.- } \\
\text { extracted FA, } \\
\text { anoxic }\end{array}$ & 22 & 10 & 19 & 8 & 14 & 8 & 12 & 6 & 27 \\
\hline $\begin{array}{l}\text { Water- } \\
\text { extracted HA, } \\
\text { oxic }\end{array}$ & 31 & 11 & 19 & 7 & 13 & 7 & 7 & 2 & 23 \\
\hline $\begin{array}{l}\text { Water- } \\
\text { extracted HA, } \\
\text { anoxic }\end{array}$ & 23 & 9 & 17 & 8 & 15 & 9 & 10 & 8 & 30 \\
\hline $\begin{array}{l}\text { Chem.- } \\
\text { extracted HA, } \\
\text { oxic }\end{array}$ & 24 & 11 & 22 & 8 & 15 & 8 & 9 & 3 & 20 \\
\hline $\begin{array}{l}\text { Chem.- } \\
\text { extracted HA, } \\
\text { anoxic }\end{array}$ & 27 & 11 & 21 & 8 & 14 & 7 & 8 & 3 & 24 \\
\hline
\end{tabular}

${ }^{\mathrm{a}}$ Aromaticity $(\%)=[$ Aromatic C peak area $(110-160 \mathrm{ppm})] \times 100 /[$ Total peak area $(0-160 \mathrm{ppm})]$ 
Table S3. Total phosphate-leachable Fe, Fe(II) and Fe(III) in the isolated SOM, FA and HA samples. All samples were prepared by dissolving the freeze-dried SOM, FA, and HA extracts (powder) in $50 \mathrm{mM}$ of phosphate buffer $(\mathrm{pH} \mathrm{7})$ at a concentration of $100 \mathrm{mg} \mathrm{C} \mathrm{L}^{-1}$. After overnight agitation at $300 \mathrm{rpm}$ at room temperature, samples were filtered through $0.22 \mu \mathrm{m}$ syringe filter (mixed cellulose ester (MCE), Millipore, Germany). Iron concentrations were quantified in the phosphate-buffer extracts with the spectrophotometric ferrozine assay in a microtiterplate assay. Errors represent the standard deviation calculated from 3 parallels. Missing data is due to concentration below detection.

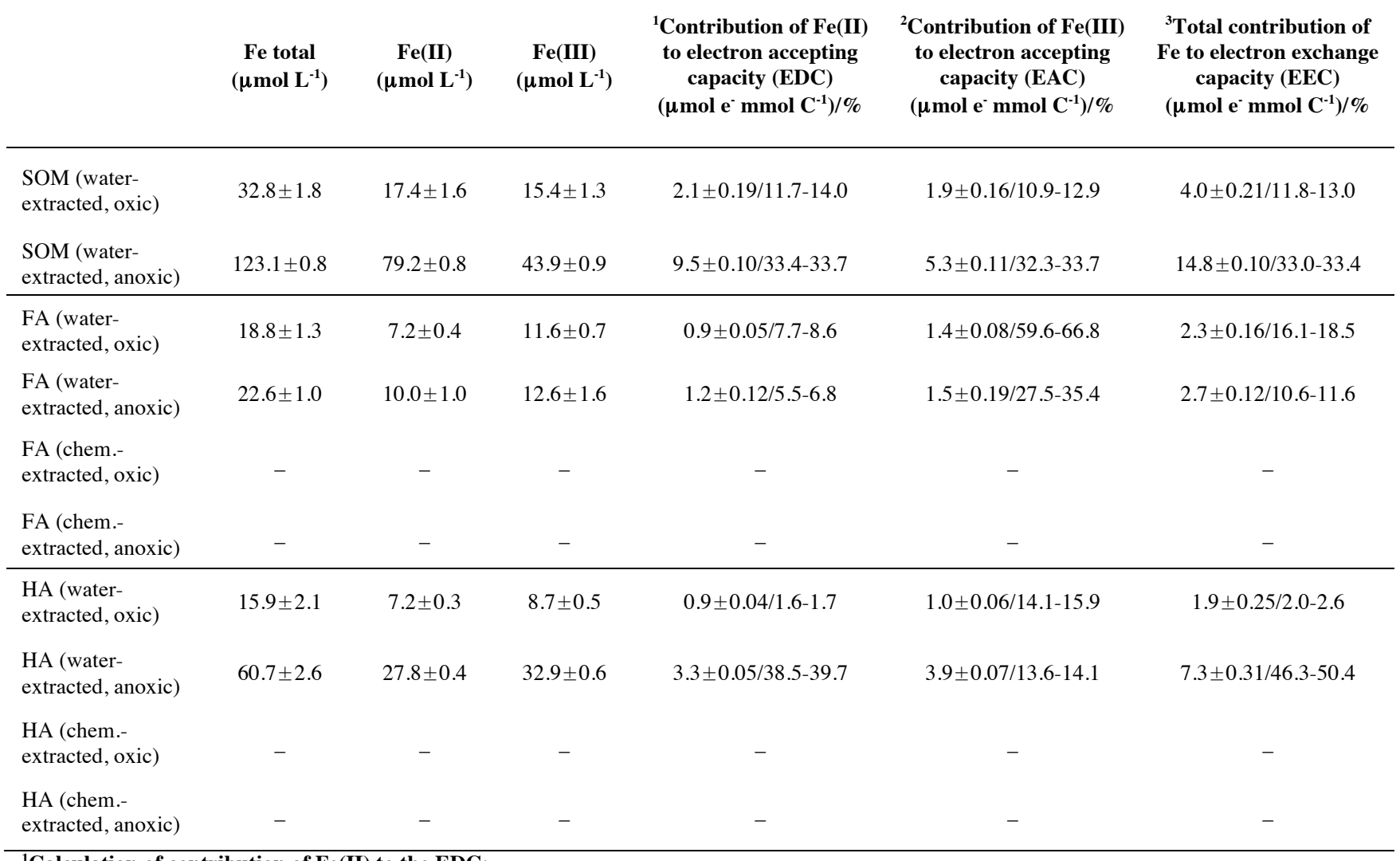

${ }^{1}$ Calculation of contribution of Fe(II) to the EDC:

Take water-extracted SOM, oxic as an example, Fe(II) concentration $=17.4 \mu \mathrm{mol} \mathrm{L}{ }^{-1}$

The volume of SOM solution used for EDC analysis is $200 \mu \mathrm{L}$

Mole quantity of $\mathrm{Fe}(\mathrm{II})=17.4 \mu \mathrm{mol} \mathrm{L}{ }^{-1} * 200 \mu \mathrm{L}=0.00348 \mu \mathrm{mol} \mathrm{Fe}(\mathrm{II})$

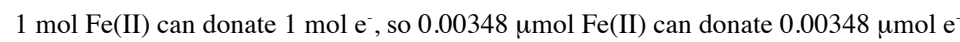

Mole quantity of $\mathrm{C}=100 \mathrm{mg} \mathrm{C} \mathrm{L}^{-1} 10^{-3} * 200 \mu \mathrm{L} / 12 \mathrm{~g} \mathrm{~mol}^{-1}=0.00167 \mathrm{mmol} \mathrm{C}$

Therefore, the contribution of $\mathrm{Fe}(\mathrm{II})$ to the $\mathrm{EDC}=0.00348 \mu \mathrm{mol} \mathrm{e} / 0.00167 \mathrm{mmol} \mathrm{C}=2.1 \mu \mathrm{mol} \mathrm{e} \mathrm{mmol} \mathrm{C}^{-1}$

${ }^{2}$ Calculation of contribution of $\mathrm{Fe}($ III) to the EAC:

Take water-extracted SOM, oxic as an example, Fe(III) concentration $=15.4 \mu \mathrm{mol} \mathrm{L}{ }^{-1}$

The volume of SOM solution used for EAC analysis is $200 \mu \mathrm{L}$

Mole quantity of $\mathrm{Fe}=15.4 \mu \mathrm{mol} \mathrm{L}{ }^{-1} * 200 \mu \mathrm{L}=0.00308 \mu \mathrm{mol} \mathrm{Fe}$

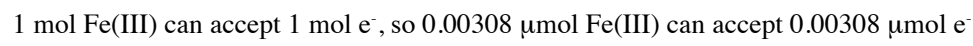

Mole quantity of $\mathrm{C}=100 \mathrm{mg} \mathrm{C} \mathrm{L}{ }^{-1} 10^{-3} * 200 \mu \mathrm{L} / 12 \mathrm{~g} \mathrm{~mol}^{-1}=0.00167 \mathrm{mmol} \mathrm{C}$

Therefore, the contribution of $\mathrm{Fe}(\mathrm{III})$ to the $\mathrm{EAC}=0.00308 \mu \mathrm{mol} \mathrm{e} / 0.00167 \mathrm{mmol} \mathrm{C}=1.9 \mu \mathrm{mol} \mathrm{e} \mathrm{mmol} \mathrm{C}^{-1}$

${ }^{3}$ Calculation of contribution of Fe to the EEC:

Take water-extracted SOM, oxic as an example, Fe total concentration $=32.8 \mu \mathrm{mol} \mathrm{L}-1$

The volume of SOM solution used for EEC analysis is $200 \mu \mathrm{L}$

Mole quantity of Fe total $=32.8 \mu \mathrm{mol} \mathrm{L}-1 * 200 \mu \mathrm{L}=0.00656 \mu \mathrm{mol} \mathrm{Fe}(\mathrm{II})$

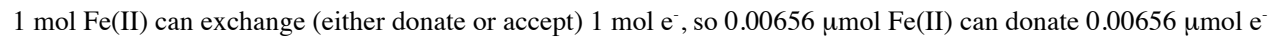

Mole quantity of $\mathrm{C}=100 \mathrm{mg} \mathrm{C} \mathrm{L}{ }^{-1} 10^{-3} * 200 \mu \mathrm{L} / 12 \mathrm{~g} \mathrm{~mol}^{-1}=0.00167 \mathrm{mmol} \mathrm{C}$

Therefore, the contribution of $\mathrm{Fe}(\mathrm{II})$ to the $\mathrm{EDC}=0.00656 \mu \mathrm{mol} \mathrm{e} / 0.00167 \mathrm{mmol} \mathrm{C}=4.0 \mu \mathrm{mol} \mathrm{e}-\mathrm{mmol} \mathrm{C}^{-1}$ 
Table S4. Summary table for the two-way ANOVA of the measured electron exchange capacity (EEC) of all extracts. The two-way ANOVA analysis was conducted using the SPSS software to test whether the oxic extraction conditions or the extraction method, or both of them have significant impact on the EEC values of the extracts. $\mathrm{P}<0.05$ indicates the rejection of the null hypotheses, meaning that the corresponding condition has significant influence on the EEC.

a'Dependent Variable: Electron exchange capacity (EEC)

\begin{tabular}{|c|c|c|c|c|c|}
\hline Condition & Sum of Squares & $\begin{array}{l}{ }^{b} \text { Degrees of } \\
\text { freedom }\end{array}$ & ${ }^{\mathrm{c}}$ Mean Square & ${ }^{\mathrm{d}} \mathrm{F}$ & $\mathrm{P}$ \\
\hline $\begin{array}{l}\text { Oxic extraction conditions } \\
\text { (oxic } v s . \text { anoxic) }\end{array}$ & 18073 & 1 & 18073.6 & $\begin{array}{c}657.912 \\
F(1.20)=4.35\end{array}$ & $<0.05$ \\
\hline $\begin{array}{l}\text { Extraction method (water } \\
v s . \text { chemical) }\end{array}$ & 21448 & 4 & 5362.1 & $\begin{array}{c}195 \\
\mathrm{~F}(4.20)=2.87 \\
.191\end{array}$ & $<0.05$ \\
\hline $\begin{array}{l}\text { Oxic extraction conditions } \\
\text { and extraction method }\end{array}$ & 9722 & 4 & 2430.8 & $\begin{array}{c}88.477 \\
F(4.20)=2.87\end{array}$ & $<0.05$ \\
\hline $\begin{array}{l}\text { Error (within group } \\
\text { variances) }\end{array}$ & 150 & 20 & 7.5 & & \\
\hline
\end{tabular}

${ }^{a}$ Three null hypotheses of the two-way ANOVA analysis:

Hypothesis $_{\mathrm{n} 1}$ : the oxic extraction conditions do not have significant impact on the measured EEC values of the extracts Hypothesis $_{\mathrm{n} 2}$ : the extraction method does not have significant impact on the measured EEC values of the extracts

Hypothesis $_{\mathrm{n} 3}$ : the oxic extraction conditions and the extraction method together do not have any significant impact on the measured EEC values of the extracts

${ }^{b}$ Degree of Freedom was calculated based on the number of variables under each condition. For example, under oxic extraction conditions, there are two variables, i.e., oxic conditions and anoxic conditions, so the degree of freedom is $2-1=1$. For the extraction method, there are five variables, i.e., water-extracted SOM, water-extracted FA, chemically-extracted FA, water-extracted HA, chemically extracted HA, therefore the degree of freedom is 5-1 =4. The degree of freedom of both conditions (the third row: oxic extraction conditions and extraction method) was calculated by multiplying the degree of freedom of oxic extraction conditions and the degree of freedom of extraction method, therefore $1 \times 4=4$.

${ }^{\mathrm{c}}$ Mean Square $=$ Sum of Square/Degree of Freedom

${ }^{\mathrm{d}} \mathrm{F}$ ratio =variance of the group means (Mean Square)/mean of the within group variances (Mean Square Error). The calculated $\mathrm{F}$ ratio should be compared to the critical $\mathrm{F}$ ratio based on the degree of freedom (as shown in the brackets), and in all cases above, the F ratio was higher than the critical F ratio, indicating the null hypotheses should be rejected. 
Table S5. Metal content analyzed by Microwave Plasma-Atomic Emission Spectrometer (MP-AES) (4100, Agilent Inc., Santa Clara, CA, USA) in the extracted SOM, HA and FA samples. Prior to the MP-AES analysis, $0.5 \mathrm{~g}$ sample was digested with $10 \mathrm{~mL} 2 \% \mathrm{HNO}_{3}$ in microwave oven at $190{ }^{\circ} \mathrm{C}(800 \mathrm{w})$ for $10 \mathrm{~min}$, after cooling down to room temperature, centrifuged for $10 \mathrm{~min}$ at $14000 \mathrm{rpm}$ and the supernatant was used for the analysis. The data for FA (chemically-extracted, oxic) and HA (water-extracted, oxic) are missing due to the lack of enough samples. The unit of all metal concentrations is $\mathrm{mg} \mathrm{kg}^{-1}$, blank means the concentration of the corresponding metal is too low to be detected.

\begin{tabular}{lccccccccccc} 
& $\mathrm{B}$ & $\mathrm{Zn}$ & $\mathrm{Ca}$ & $\mathrm{Mg}$ & $\mathrm{Cu}$ & $\mathrm{Ag}$ & $\mathrm{Ba}$ & $\mathrm{Mn}$ & $\mathrm{Pb}$ & $\mathrm{Al}$ & $\mathrm{Ga}$ \\
\hline $\begin{array}{l}\text { SOM (water- } \\
\text { extracted, oxic) }\end{array}$ & 1.65 & 0.04 & 10.09 & 3.03 & 0.10 & 0.02 & 0.07 & 3.82 & 0.10 & 0.99 & 0.33 \\
$\begin{array}{l}\text { SOM (water- } \\
\text { extracted, anoxic) }\end{array}$ & 0.11 & 0.13 & - & 8.97 & 0.11 & 0.01 & 0.68 & 10.64 & 0.14 & 12.64 & 0.01 \\
\hline $\begin{array}{l}\text { FA (water- } \\
\text { extracted, oxic) }\end{array}$ & 0.34 & 0.01 & 14.02 & 0.20 & 0.08 & 0.01 & 0.03 & 0.45 & 0.07 & 0.26 & 0.03 \\
$\begin{array}{l}\text { FA (water- } \\
\text { extracted, anoxic) }\end{array}$ & 0.06 & 0.01 & 0.84 & - & 0.05 & 0.01 & 0.01 & 0.31 & 0.03 & 0.82 & 0.02 \\
$\begin{array}{l}\text { FA (chemically- } \\
\text { extracted, anoxic) }\end{array}$ & 0.09 & 0.11 & - & 11.13 & 0.19 & 0.02 & 1.05 & 3.40 & 0.12 & 14.87 & 0.01 \\
\hline $\begin{array}{l}\text { HA (water- } \\
\text { extracted, anoxic) }\end{array}$ & 0.03 & 0.03 & 6.41 & 2.78 & 0.01 & 0.01 & 0.26 & 2.07 & 0.10 & 19.64 & 0.02 \\
$\begin{array}{l}\text { HA (chemically- } \\
\text { extracted, oxic) }\end{array}$ & 0.08 & 0.04 & 0.03 & 7.91 & 3.92 & 0.09 & 0.02 & 0.32 & 1.6 & 0.15 & 64.12 \\
$\begin{array}{l}\text { HA (chemically- } \\
\text { extracted, anoxic) }\end{array}$ & 0.02 & 0.02 & 0.01 & 6.46 & 2.94 & 0.05 & 0.03 & 0.09 & 0.15 & 0.09 & 7.14 \\
\hline
\end{tabular}




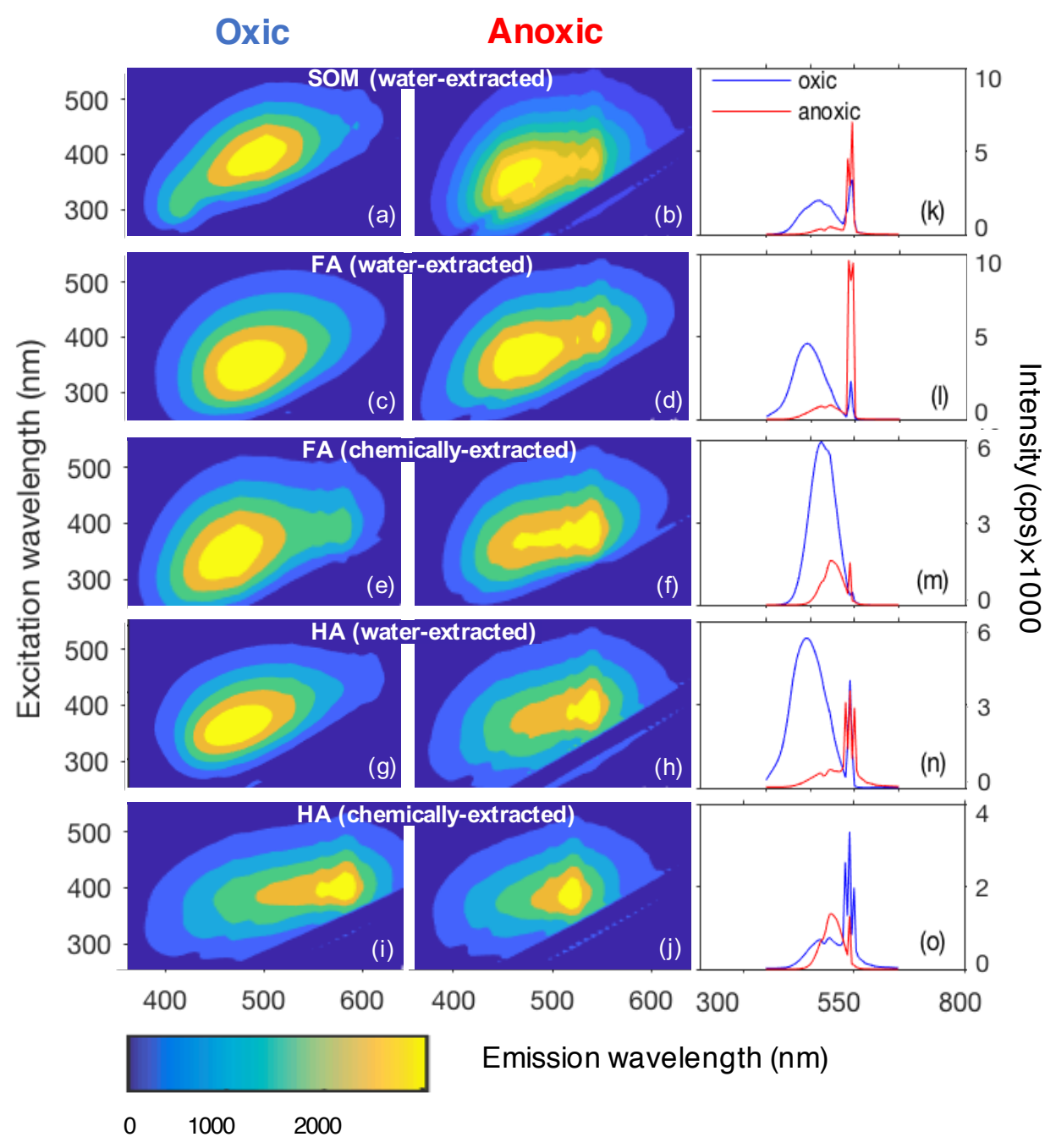

Figure S1. Fluorescence excitation-emission matrices (EEM) of SOM (a,b), FA (c-f), HA (gj) and emission spectra at a fixed $440 \mathrm{~nm}$ excitation wavelength for SOM $(\mathrm{k}), \mathrm{FA}(1, \mathrm{~m})$ and HA $(\mathrm{n}, \mathrm{o})$. Freeze-dried SOM/FA/HA powders were dissolved in Milli-Q water $(\mathrm{pH} 7)$ at a concentration of $100 \mathrm{mg} \mathrm{C} \mathrm{L}^{-1}$ and the solutions were agitated for $12 \mathrm{~h}$ at $300 \mathrm{rpm}$ at room temperature, samples were then filtered through $0.45 \mu \mathrm{m}$ syringe filters (mixed cellulose ester (MCE), Millipore, Germany). For fluorescence analysis, samples were prepared by stepwise dilution of extract solutions with Milli-Q water $(\mathrm{pH} 7)$ until absorbance values of 0.300 at 254 $\mathrm{nm}$ wavelength were reached. A wavelength step size of $10 \mathrm{~nm}$ was used for the collection of EEM spectra. The excitation and emission wavelength ranges were from 200-600 and 300$700 \mathrm{~nm}$, respectively. A shift of the emission peak to higher wavelengths indicates a higher aromaticity of the OM compounds. 


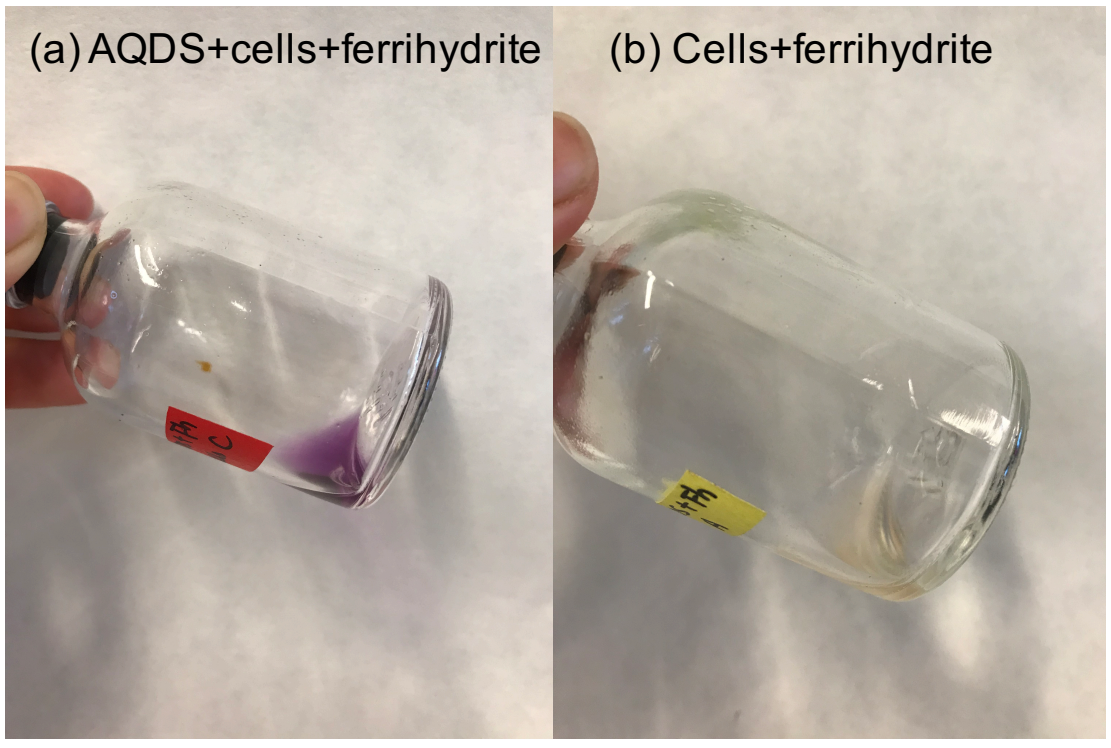

Figure S2. Addition of ferrozine to incubation bottles at the end of the experiment shows sorption or precipitation of $\mathrm{Fe}(\mathrm{II})$ at the glass walls of experiments containing AQDS, Shewanella oneidensis MR-1 and ferrihydrite (a) but not when containing Shewanella oneidensis MR-1 and ferrihydrite without AQDS (b). Before adding the ferrozine solution, original solutions in the bottles were discarded completely in the anoxic glovebox. 


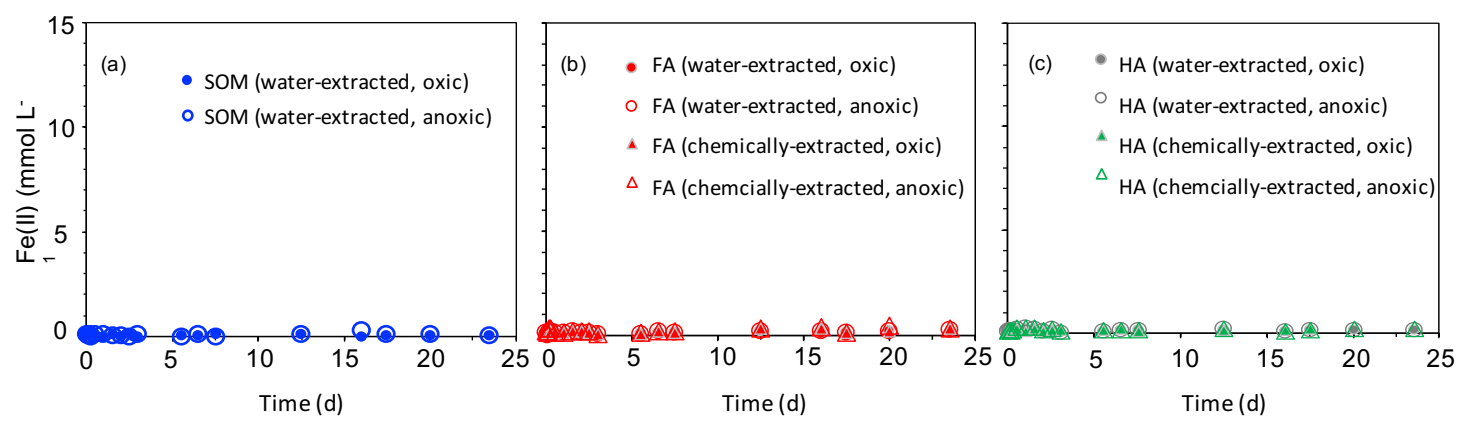

Figure S3. Abiotic reduction of ferrihydrite $\left(15 \mathrm{mmol} \mathrm{L}^{-1}\right)$ in the presence of $50 \mathrm{mg} \mathrm{C} \mathrm{L}^{-1}$ SOM (A), FA (B) and HA (C) and $15 \mathrm{mmol} \mathrm{L}^{-1}$ lactate, presented as total Fe(II) formed over time. All setups were incubated in air-tight $100 \mathrm{~mL}$ glass serum bottles flushed with $\mathrm{N}_{2}$ at $30^{\circ} \mathrm{C}$ in the dark. 

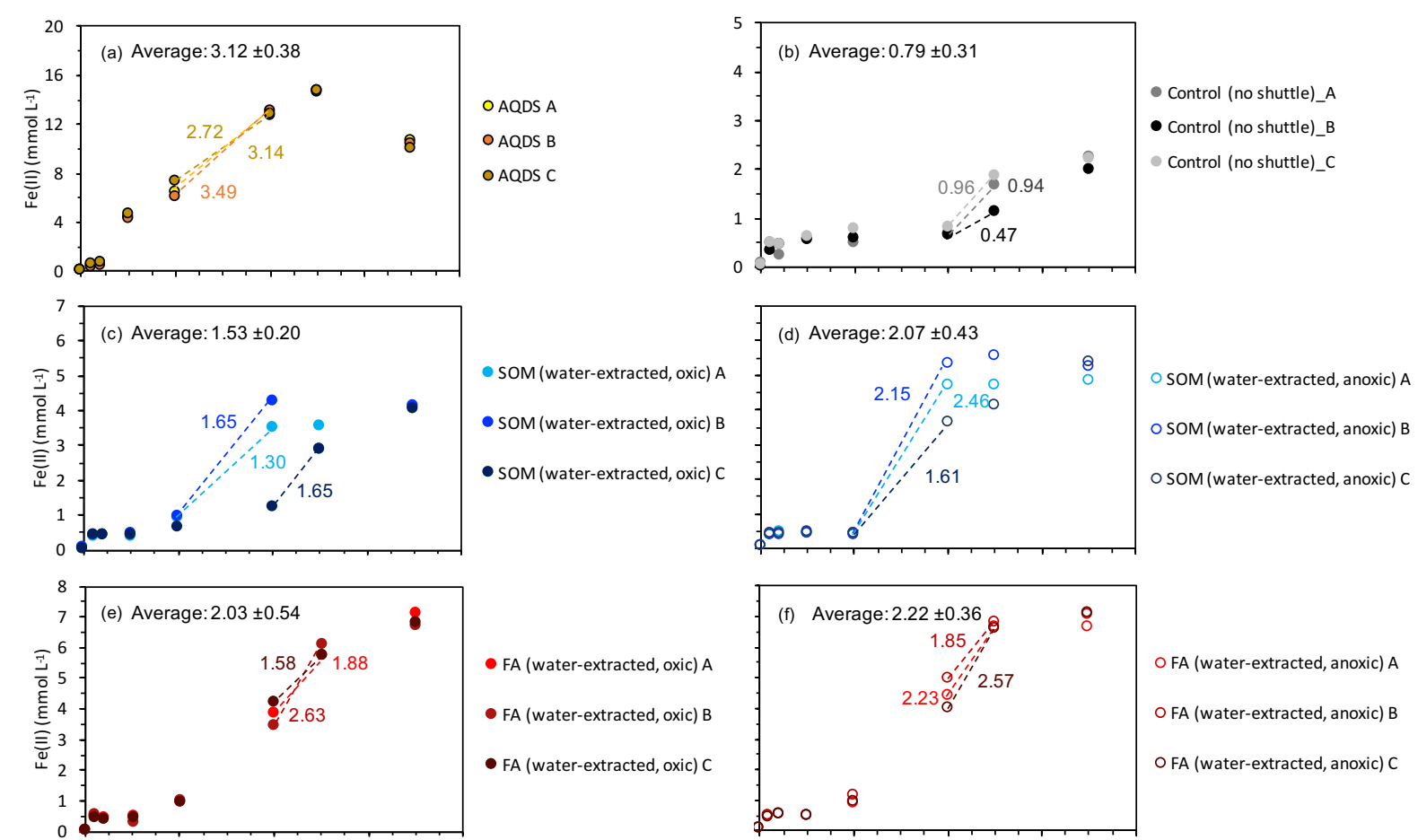

- SOM (water-extracted, oxic) A

- SOM (water-extracted, oxic) B

- SOM (water-extracted, oxic) C
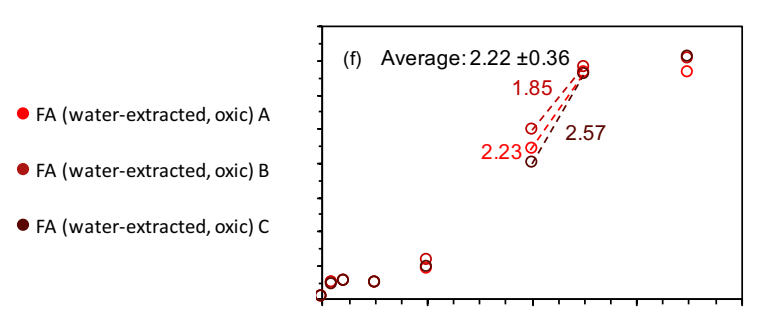

OFA (water-extracted, anoxic) A

o FA (water-extracted, anoxic) B OFA (water-extracted, anoxic) C

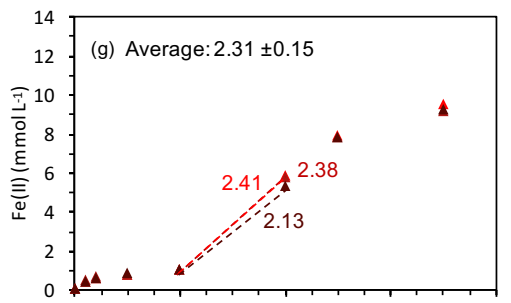

FA (chem.-extracted, oxic) A

$\triangle$ FA (chem--extracted, oxic) B

FA (chem.-extracted, oxic) C

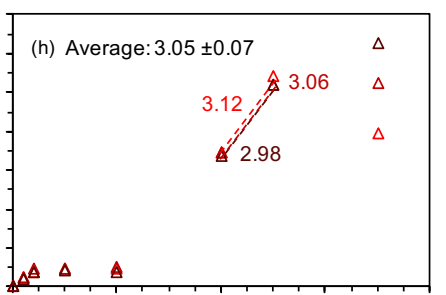

$\triangle F A$ (chem.-extracted, anoxic) A

$\triangle F A$ (chem-extracted, anoxic) $B$

$\triangle F A$ (chem.-extracted, anoxic) C

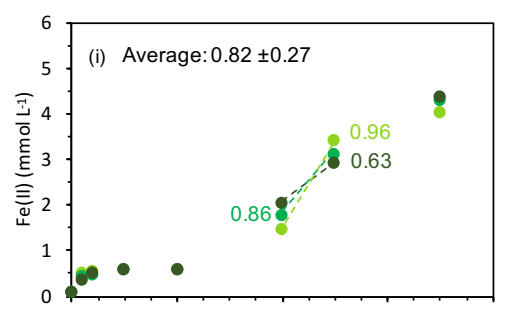

- HA (water-extracted, oxic) A

- HA (water-extracted, oxic) B

- HA (water-extracted, oxic) C

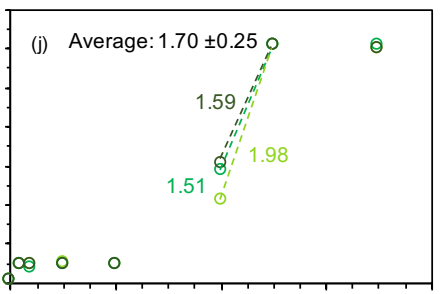

HA (water-extracted, anoxic) A

O HA (water-extracted, anoxic) B O HA (water-extracted, anoxic) C

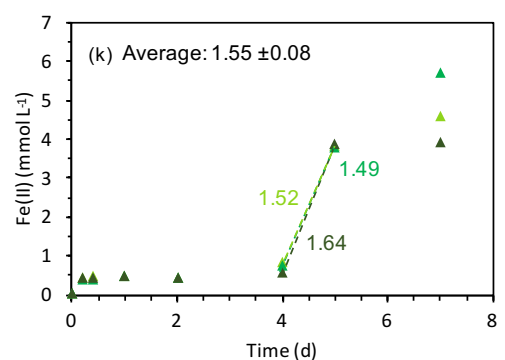

$\triangle \mathrm{HA}$ (chem.-extracted, oxic) A

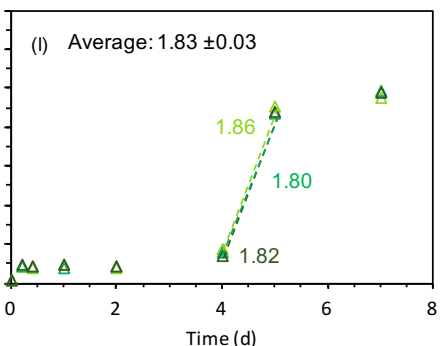

$\triangle \mathrm{HA}$ (chem.-extracted, anoxic) A

$\triangle H A$ (chem.-extracted, anoxic) B

$\triangle \mathrm{HA}$ (chem.-extracted, oxic) B

$\Delta$ HA (chem.-extracted, oxic) C

$\triangle H A$ (chem.-extracted, anoxic) C

Figure S4. Calculation of the fastest initial microbial Fe(III) reduction rates in setups amended with SOM (a-b), FA (c-f), HA (g-j). The reduction rate was calculated separately for each of the triplicates. The average of the three rates was calculated and used for the correlation of reduction rate with either EEC or EAC. The standard deviation for the average of the three rates was calculated and is indicated in each panel (e.g. AQDS, 3.12 \pm 0.38 ). 